\title{
A Discriminação do Negro como Fato Estruturador do Poder ${ }^{1}$
}

Wilson do Nascimento Barbosa ${ }^{2}$

\begin{abstract}
Resumo: Este texto é uma compilação da palestra proferida para o encerramento do curso Debates sobre África, Colonialidade e Construção de Identidades, no Departamento de História da FFLCH-USP, em novembro de 2008. Discute-se a problemática das relações raciais e o mercado de trabalho no Brasil, o racismo vigente na estrutura do Estado e o lugar destinado ao negro neste cenário. A partir daí explora-se os conceitos de raça, negritude, poder, dominação e castas suscitadas pelo debate. A desconstrução do racismo no país é apresentada como luta política dos movimentos negros, fazendo-se necessário, para isso, compreender como se dão as ações fascistizantes do Estado articulado ao modo de produção capitalista.
\end{abstract}

Palavras-chaves: relações raciais; mercado de trabalho; história do negro no Brasil.

Abstract: This text is a compilation of the speech pronounced for the closing of the course Debates on Africa, Colonialism and Construction of Identities, at the History Departament, FFLCH-USP, November of 2008. Social and ethnic relations and the labor market in Brazil are discussed to bring light on the presence of racism as strategy of State and the resulting place to Black people in this scene. The concepts of race, negritude, power, domination and caste are worked in the debate. De-construction of racism in the country is presented as an object of the political struggle of Black movements. It demands a full comprehension of fascitizing actions and proposals outcoming from the State, as result of its articulation with the capitalistic mode of production.

Key-words: social relations; labor market; history of Black people in Brazil.

\section{Introdução}

Vou começar com um comentário de jornal. Na Folha de São Paulo de hoje tem a notícia: "Renda do negro é metade da renda do não-negro". É o que nós já sabemos. Mas, no argumento corrente do movimento negro diz-se que o Estado brasileiro é um estado fascista ou parafascista. É um dos argumentos mais hostilizados pelas pessoas de esquerda que não são negras. "Mas como?! é um estado democrático, depois de 1990 passamos a eleger nossos presidentes, etc, etc." Isso aqui não é uma aula, são dados apanhados pelo SEADE e DIEESE para a cidade de São Paulo que é o lugar mais capitalista do Brasil. Não existe uma explicação para o que se lê no jornal. Como é que trabalhadores desempenhando as mesmas funções, um ganha dois reais e outro um. Não tem uma explicação. Não tem uma explicação de classe, não tem uma explicação política para isso. Só tem uma explicação: estrutural. Por quê? Porque a sociedade brasileira é montada, foi e existe por causa da superexploração do negro. O negro é sempre a mão-de-obra primeira a ser alijada no mercado de trabalho, a última a ser procurada e a pior remunerada. Consequentemente, nós podemos dizer que a estrutura do capitalismo no Brasil está montada em cima da exploração do negro. Portanto, ela não é uma estrutura social. Ela é

\footnotetext{
${ }^{1}$ Palestra de Encerramento do Curso: Debates sobre África, Colonialidade e Construção de Identidades. Departamento de História - FFLCH-USP - 19/11/2008, 10 horas. Organizado pelo NEACP - Núcleo de Estudos de África, Colonialidade e Cultura Política e SANKOFA - Revista de História da África e de Estudos da Diáspora Africana.

2 Professor titular de História Econômica no Departamento de História da FFLCH-USP. Especialista em Cultura Negra no Brasil e autor de vários textos na área entre eles o livro Cultura Negra e Dominação, Editora Unisinos, 2006.
} 
uma estrutura étnica. Ou ainda: é uma estrutura social de base étnica. Por causa de ela ser assim é que o negro tem a posição social que tem. A Igreja Católica já assumiu a falsidade dessa posição, nos anos (19)80. Lembro-me que houve um seminário no Rio de Janeiro, em 1988, durou uma semana inteira num convento. Estavam presentes representantes de comunidades indígenas da América Central, do Caribe e da América do Sul. Toda sessão que os padres ali começavam, eles pediam desculpas àquelas comunidades indígenas, por elas terem sido tratadas pela Igreja como camponeses e não como um povo determinado. Isso há vinte anos. Porque se nós olharmos para o camponês peruano, ele é camponês porque é indígena. O camponês boliviano é camponês porque é indígena. Não é camponês e por acaso indígena. Se você for branco na Bolívia você não é camponês; é fazendeiro, funcionário público, ministro, outra coisa. Então, esses lugares não são lugares gerados por uma relação de competição num mercado em formação. São lugares institucionalmente designados por quem detém o poder. Quem detém o poder diz o que o outro pode ser ou vai fazer no Brasil. Por que no Brasil os negros são os trabalhadores? Porque eles foram trazidos da África para serem trabalhadores. Os indígenas foram apanhados nas aldeias para serem trabalhadores. Aquele que não queria ser trabalhador era eliminado fisicamente. $\mathrm{Na}$ verdade, não faria muito sentido tratar da mesma forma fenômenos que mal acontecem e fenômenos persistentes, que se alteram muito pouco ao longo do tempo. Fenômenos cujos efeitos se desdobram, acarretando similaridades, certamente expressam uma longa duração no tempo, ou seja, caracterizam uma estrutura. Nesse caso, tanto a prática do racismo quanto a inoperância, a antecedência e até a organização do racismo por parte do Estado indicam uma situação mais profunda, que não deve ser compreendida ou tratada de modo superficial. As estruturas são capazes de se expressar como forças persistentes também no quadro da mentalidade, particularmente como uma forma ativa de ideologia social.

É claro que tinha o escravo a oportunidade de fugir. Mas, todos nós já vimos uma gravura de um capitão-do-mato. Quando se olha para aquela gravura, se tiver uma dúvida, coloca uma lente em cima, você o verá se aproximando, verá que não é brincadeira. Um indivíduo armado com um pedaço de pau, com um facão, perseguido por um homem a cavalo e doze cães. Cães que comiam carne humana, que é um pequeno detalhe que não ensinam no ginásio, nem no colégio, às vezes, nem na universidade. É preciso trocar o professor para poder ouvir essa frase. Cães se alimentavam de carne humana, costumeiramente no Brasil, carne de negros. E pela América Latina toda, carne de indígenas. O colonizador tinha o direito de fatiar e distribuir as pessoas para os cães. Então, 
era um problema sério. Você já passou na porta de uma casa e viu a "rapaziada" lá nervosa. Pense que depois, à medida que foi se tornando um Estado mais complexo, a "rapaziada" foi crescendo, botando uniforme, um crachá de identificação, recebendo doz̧es do Canadá. Foi se aperfeiçoando e chegou-se ao Estado que temos hoje, que é um Estado de genocídio. Trata-se de eliminação física dos que se opõem ao sistema. Caso se opuser ao sistema, corre-se o risco de ser eliminado fisicamente. Se não, há um lugar para você, é-se encaixado que nem um dominó. Então, a estrutura do Estado brasileiro, como toda estrutura é dialética. Ela tem uma dupla face. É democrática para o não-negro e não é democrática para o negro. Aquilo que o Estado alemão era acusado de ser para o trabalhador alemão - o Estado de dupla-face - no Brasil funciona não para o trabalhador, mas para o negro, primeiro para o negro, depois para o trabalhador. Talvez seja um dos componentes do porque de o trabalhador ter uma consciência de classe tão ruim. Se for trabalhar em uma empresa e não for negro, o salário não vai ser igual ao dos negros. Está dito aqui pelo DIEESE.

Um dos depoimentos mais anti-racistas que já ouvi na minha vida foi de um companheiro uruguaio na Europa. Éramos, ele e eu, exilados políticos. Ele sentou-se ao meu lado (ele havia trabalhado aqui no Brasil). Disse que tinha vergonha porque, pelo simples fato dele ser um uruguaio branco, era sempre nomeado capataz nas empresas em que ia trabalhar e sempre recebia advertência contra os trabalhadores negros: "você tenha cuidado com essa negrada aí, são um bando de vagabundos, picaretas, não querem fazer nada". Ele disse que tinha vergonha, mas como era foragido político do Uruguai não falava nada. Passou uma tarde sentado comigo contando essa experiência de Brasil. Que a gente não vê, quer dizer, quem não tem o problema não o vê. Quem tem o problema e vê recebe um selo de paranóico, mania de perseguição, sentimento de inferioridade. Mas, como o indivíduo não terá sentimento de inferioridade se ele é tratado como inferior? É evidente que ser tratado como inferior gera um sentimento de inferioridade. Se olharmos para o Brasil, a maioria da população brasileira é de negros, mestiços de negros com indígenas e indígenas. Mas, recentemente, até o governo Lula, essas situações étnico-sociais apareciam na mídia e na linguagem oficial como minorias. Deve ser por causa do "penteado". Se não for o "penteado" ele não é minoria, pertence a uma camada étnico-social perfeitamente conhecida, definida, etc. Então, ao invés de classificar o tipo, se classifica o paradoxal no tipo. Essa é a sociologia brasileira, com raras e honrosas exceções, como Otávio Ianni que escreveu um texto que até hoje é criticado. Diz Ianni ali que o Brasil não era uma sociedade formada por classes, e sim por castas. Ao olharmos o Brasil colonial veremos castas. O 
africano ao sair da África já estava definido o lugar que iria ocupar. Isso não é uma classe social, é a conseqüência feita no raciocínio de Ianni. Na nossa sociedade não existiria o livre mercado, as castas continuariam existindo. Você é indicado para a casta que corresponde à sua aparência. Dizem que o Ianni estava "maluco" quando escreveu esse ensaio, "é incompatível com o marxismo", etc. Uma vez, participando de uma mesa com Ianni no Rio de Janeiro, alguém do público perguntou a ele se revisaria aquele texto, ele disse: "Não, é da mais completa atualidade, o senhor não acha; o senhor leu?” O Brasil, evidentemente, vem de um sistema de castas. Hoje nós somos todos assalariados, mas com critérios nãomercadológicos, e sim, com os que previnem a competição social. Um regime que não está aberto à competição social não é “capitalista de livre mercado”. É até um regime em que o capital sofre certas restrições. É difícil o capital mercantil se transformar em industrial num lugar em que não existe a livre competição. A primeira competição necessária para existir o capitalismo não é a do capital, e sim, a da força-de-trabalho. É o mercado de trabalho que forma o capitalismo. O capital sempre existiu, na Roma antiga existia capital. Mas, não é o capital que forma o capitalismo, é o oposto do capital, o social, que é o proletariado industrial, a força de trabalho moderna. Daí, se não há um mercado de trabalho, não há, necessariamente, capitalismo. Ter-se-á um regime de exploração baseado no capital, mas pode ser outras formas. Como no século XVIII e XIX, o Brasil tinha formas capitalistas, mas não era um regime capitalista. Tampouco ele era também um mercado integrado. Tinha capitanias, a Bahia, Pernambuco, Maranhão. Cada uma acorrentada a Lisboa, como um navio independente no porto. Ele não se comunica com outro, só se colocar uma prancha nele. Essa "prancha" era autorizada; só o capitão-governador podia fazer uma comunicação oficial de uma capitania com a outra. Todas se comunicavam com Lisboa, e ela se comunicava com cada qual. Chamar aquilo de "sociedade brasileira" é uma força de expressão. Trata-se de uma adivinhação, que os historiadores têm com essa extraordinária capacidade de adivinhar. Eles olham para o passado e já sabem qual o futuro que será e que qualifica aquele passado. Isso é o dom que o historiador tem; outros cientistas sociais são desprovidos disso. Então, evidentemente, em 1950 ou 2000, podemos olhar para o passado e dizer: qual será o futuro que esse passado poderá produzir? O que essas províncias poderão produzir? Trata-se de adivinhar após o sucedido. Uma República unitária, etc. Só o historiador tem esse poder extraordinário de previsão, esse “dom”. Ele é tocado por Deus para saber qual será o futuro de um tipo de estrutura que está estudando. E aí ele faz essa coisa extraordinária que são previsões do passado. Como se sabe o que era arcaico em 1810? Consultando o futuro. Quero, então, levantar algumas coisas. A minha premissa é 
que esse caráter duplo do Estado brasileiro leva a uma situação de uma estrutura de fascistização que não é uma novidade no Brasil. Ela é uma característica do mundo em relação ao trabalhador. A exclusão do trabalhador disfarçada de inclusão. A inclusão do trabalhador é lúdica, apenas. Não é para valer quanto à distribuição do rendimento. A ação do Estado pró-racismo como um fato estrutural constitui-se um acumulado ao longo da História, facultando aos que professam o racismo tratá-lo como um consenso social e até como algo natural. Nesse sentido, os racistas - particularmente os intelectuais que o são - e que no Brasil talvez seja a maioria dos intelectuais, conseguem ver nas estatísticas antiracistas um perigo político e um perigo social. O perigo político seria uma suposta racialização das relações políticas. O perigo social seria uma divisão da sociedade entre negros e não-negros. Atribuem assim aos outros a esquizofrenia que lhes é própria. A prática racista - inclusive sob comando do Estado - é que leva à elaboração e proposição de estratégias anti-racistas. No entanto, os racistas julgam que o controle do Estado por eles e o monopólio de elaboração de estratégias para conduzir o país seria posto em risco, caso as estratégias anti-racistas fossem implementadas.

\section{O domínio e seus motivos}

A estrutura de domínio da sociedade brasileira se caracteriza pelo (a) domínio de grupos organizados e excludentes, (b) pelo regime de opressão e (c) pelos motivos e metas que tais grupos estabelecem periodicamente, para perpetuar sua dominação. A sociedade brasileira é de tal modo desatualizada, mas identificada com a auto-imagem européia, que o seu ego é entendido como europeu.

Tais grupos organizados que controlam o país constituem uma espécie de revisão filmográfica, ou fundição de escórias, de tudo que governou o Brasil com tudo que poderia governá-lo. O exemplo de tudo que governou são os descendentes da lavoura cafeeira escravocrata. Eles permanecem, e fornecem o substrato da elaboração legal e da justificação essencial do Estado e do poder social brasileiros. O exemplo de tudo que poderia governar é a máquina sindical corrupta e corruptora a serviço do poder centralizado.

O regime de opressão é aqui uma síntese da gestão colonial com os mecanismos do pragmatismo fascista que se espraiou pelo mundo no século passado. A essência da postura fascista está no arrivismo da elite autoproclamada branca, que controla todas as instituições do Estado que representem poder. A divisa dos detentores do poder é monopolizá-lo. Não são toleradas quaisquer críticas ou proposição de reformas que incomode os que 
assaltaram, os que agarraram, os que monopolizam o poder. Dessa forma, sendo o Estado brasileiro uma proposição aparentemente de homogeneidade étnica, a burocracia que conforma tal Estado só pode expressar tal homogeneidade. A homogeneidade de um lado só.

Já se falou que o embranquecimento é o único caminho para a maioria escapar ao carimbo de perdedores, na procura de compensar-se, enquanto indivíduos, no espelhamento do ego do branco, através de inúmeras tentativas de (1) reconhecimento societário e (2) ascensão individual, que se repetem ridiculamente a cada geração. Ainda anteontem via eu no noticiário (dia 17) o presidente da República aconselhar os pobres a ascenderem individualmente através dos esportes. Mesmo que exportássemos todos os atletas e pagodeiros negros - fabricados em série pelo ministro dos Esportes - para a China e para a Índia, tal solução ainda seria a solução de uma minoria pouco significativa.

Como a maioria não pode valer-se da solução de atletismo proposta pelo presidente, o genocídio praticado pelas forças da ordem continuará sendo o melhor remédio.

A solução desportista é sem dúvida uma das metas estabelecidas pelos grupos dominantes para os outros, ou melhor, para o Outro. Os motivos e metas que os grupos brancos no poder estabelecem para si mesmos são - evidentemente - outros. Para os dominadores, o Estado oferece dois circuitos enormes para se apropriar dos recursos do país e do dinheiro público:

(a) um circuito legal, espécie de Interlagos, onde podem praticar tais grupos, sob o aplauso da multidão, as piruetas que os levam à ascensão material certa e garantida; e (b) um circuito ilegal, vazado aqui e ali pela própria imprensa a seu serviço, onde as centenas de bilhões de reais arrecadadas da população a cada ano sofrem o destino das metamorfoses. Destas ambas estão excluídos os candidatos a desportistas do presidente.

Como no momento o mundo acabou de entrar numa crise, o circuito legal perde importância e o circuito ilegal aumenta sua importância. Os motivos que são periodicamente revisados pelos grupos dominantes não incluem para a sociedade a bumanização do negro ou ainda o fim da política de genocídio. Segundo os serviços de saúde, no ano passado morreram no país cerca de 276 mil pessoas de doenças cardiovasculares, 176 mil de câncer e 137 mil de assassinatos e acidentes de trânsito. Dessas vítimas, o negro se constitui maioria absoluta, em desproporção com sua composição percentual da população total. Esta situação se agrava muito, quanto às vítimas do assassinato oficial. Quando você aplica as técnicas metodológicas de desconstrução à ação permanente do Estado brasileiro, você não pode deixar de ver o que nele é permanente. Ou seja, a prática racista, a 
manutenção das instituições falidas, a proteção ao compadrismo e à reprodução das classes dominantes sem competição, porque a competição é o que deveria ocorrer na chamada sociedade aberta. A decomposição analógica da ação do Estado demonstra nele um núcleo duro, que elabora suas estratégias, e que é inacessível pelos processos eleitorais da chamada democracia formal, atualmente reinstituída. E não apenas isto: como um organismo vivo, o Estado consegue bloquear e gradativamente eliminar os focos de estratégias anti-racistas que eventualmente venham a se constituir. Observe como gradativamente avacalham tanto (a) a política de quotas para pobres na universidade - alegando que são quotas para negros - quanto o ambiente para a prática da Lei no 9.394(20/12/1996) que tornara obrigatório o ensino sobre história e cultura afro-brasileira. Há escolas públicas e regiões escolares, como em Santos, que os professores não podem sequer citar esta Lei.

Assim, o modelo racista-capitalista vigente, montado sobre a opressão raça-classe, continuará a rolar processo abaixo, promovendo a violência à dialética fundamental de sua dinâmica.

Os motivos dos grupos dominantes estão certamente em outra parte: visitar o Papa, obter um passaporte italiano, exportar mais produtos primários ou salvar a carteira hipotecária norte-americana. São estas preocupações que expressam o sucesso dos vencedores, porque tais vencedores, principalmente os neocoloniais, não pertencem apenas a este ou aquele projeto passado de país, mas expressam o mundo bush da globalização. Retorna-se aqui à negatividade da formação das identidades. Enquanto isso, o povo brasileiro, formado por este ou aquele estamento étnico, busca situar-se rente a uma suposta identidade brasileira. Esta mesma identidade é negada diariamente e periodicamente nos motivos dos grupos dominantes, que nela vêem um empecilho à liberdade do mercadejar e, dispor, portanto, neocolonialmente do espaço que ainda logram administrar. É somente sua função de intermediação na divisão internacional do trabalho (D.I.T.) que faculta a semelhantes grupos tanto o status psicológico quanto o status social de classe dominante da neocolonia, ambos stata concedidos desde fora, desde o mundo do europeísmo. Daí compreender-se que seus motivos sejam os motivos do europeísmo e não a potencialidade de um ver-o-mundo desde a situação de força periférica.

Percebidos assim os motivos dos grupos dominantes dentro da ideologia social europeísta, cabe indagar quais as metas que semelhante europeísmo pode indicar para uma maioria periférica neocolonizada. Serão tais metas expressivas da cultura ocidental cristã em normas abstratas ou expressarão apenas conveniências de ocasião, peças do pegar-ou-largar das crises de mercado? 


\section{A divisão periférica na sociedade pós-industrial}

O grau de putrefação da sociedade pós-industrial não oferece qualquer abrigo aos contorcionismos mentais da velha moralidade ocidental-cristã: não há aqui (1) projeto algum de liberdade, qualquer (2) proposição de igualdade; ou ainda, (3) sociedade baseada no direito. Ou pior, inexiste qualquer (4) proposta de vigência de ética universal. É evidente que tudo isso subsiste no nível da parolagem. A repetição midiática, em cada empresa privada, em cada escola, em cada círculo enfim, dá a mentira de que está vigente a moralidade ocidental-cristã; é o primeiro atestado de seu desaparecimento no mundo neocolonial. EUA e França guerreiam pelos minérios preciosos do Congo por detrás dos tutsis e do exército local. As tropas norte-americanas garantem a liberdade de exportação do petróleo no Iraque. Os governos centrais vencem a crise a cada trimestre e a vêem se reinstalar no trimestre seguinte. Em um mundo em que não é possível permitir a existência de forças de mudanças, não há como dialogar com as mesmas, nem processar gradualismos democráticos. Não há lugar para liberdade ou igualdade que sejam verdadeiras.

Uma vez que a vigência da moralidade ocidental-cristã está sendo proclamada, as amplas massas dominadas podem se dirigir a todos os templos cristãos da sociedade e produzir ou adotar aí todas as explicações necessárias à perpetuação da ideologia social dominante. Assegurada desta forma a alienação das massas quanto ao caráter político do processo, o cinismo vigente pode publicamente expressar a desmoralização da ação política. No lugar da ética universal, se instala a prática social vigente. Esta está dotada de sua eficiência corruptora, que é a ideologia política que os grupos dominantes realmente necessitam e preferem.

Para aqueles que não representam o status quo, nem assimilam sua ideologia social, sua ideologia política pragmática é igualmente insuportável. A mentira apresentada como verdade caracteriza o limiar desta época. Potencialidades de mudanças se foram com o mundo do industrialismo. A ausência de forças para uma mudança positiva caracteriza a sociedade pós-industrial. Os impactos ideológicos da sociedade pós-industrial tipificam a mentalidade da dominação periférica, dela fazendo uma pragmática, que tem a pretensão de oferecer (1) condições tecnológicas para (2) produzir um padrão de vida em elevação, com (3) segurança material, sustentada pela (4) piora do Outro. Estas quatro promessas constituem uma nova mitologia, uma crença a se expandir quotidianamente, em favor do cinismo e do individualismo consumista. 
O desenvolvimento desta mentalidade pragmática pós-industrial coisifica o quotidiano e todos os aspectos da vida da neocolônia. Forma-se para os grupos dominantes e seus apoiadores societários um patamar pragmático e de aparência tecnológica, com uma superioridade formal tecnificada, que permite reproduzir localmente pedaços da vida da metrópole, centro do ideário dos grupos dominantes. Estes enclaves socioculturais de cópia metropolitana têm dupla função: (a) de um lado, garantem a dependência econômica das metrópoles, com a venda de produtos primários e a compra de tecnificação produtiva e cultural; (b) do outro lado, garantem a exclusão do "povão", propiciando o prazer máximo da ausência de solidariedade, qual seja, ter certeza da piora do Outro. Esta sociedade neocolonial carregada e construída sobre a culpa encontra assim a satisfação do seu Eu masoquista.

O culto da prática social vigente como uma ideologia do pragmatismo local é a faceta possível do cinismo fascitizante das metrópoles, é a sua existência nas condições de neocolonialidade. Ela permite manter a massa neocolonizada num patamar diferenciado, em que, ao mesmo tempo em que se lhe preserva a diferença, faculta explorá-la. Esta massa atirada para um patamar oposto ao da dominação, situada, portanto, num patamar de instintos subsociais, vê-se fragmentada em inúmeras tribos, distorcidas e de novo forjadas pela centralidade midiática. Assim, por exemplo, com a falsa modernidade pós-industrial, está em moda aqui o salvacionismo neopentecostal, que nada mais é que um lugar vazio das antigas promessas ocidental-cristãs. Nesse lugar vazio, dá-se uma sobreexploração extra das massas desprovidas de ideologia própria, desprovidas de postos-de-trabalho permanentes, desprovidas de participação na cultura formal dominante, etc. Ali, associam-se (1) o desenraizamento da alma, desprovida de sua experiência anterior; (2) o rebaixamento do horizonte político, restabelecido pelo curral eleitoral; (3) e o oportunismo anti-solidarista, justificado na negativa das organizações políticas de massa, sob a promessa de um progresso individual, assegurado por um pacto com o próprio Deus. "Deus é fiel" é a típica divisa de inversão, em que o fiel é tornado - pelo falso pregador - um deus, e Deus é tornado invertidamente em simples servidor. $\mathrm{Na}$ teologia da metrópole, um deus que fosse fiel ao homem não passaria de um demônio.

É assim que neste patamar de instintos subsociais se agita e se debate uma massa acéfala, tornada uma besta a serviço potencial do fascismo. Ela pode ser alimentada por todas as subideologias fabricadas com base em fatos que confirmam a sabedoria pragmática. Essa massa fascitizada pode ser virada pelo avesso pelo Estado parafascista e sua tecnologia neocolonial. Assim como só uma força de fora foi capaz de gerar tal 
armadilha que ela representa, tudo indica que só fatos gerados fora podem levá-la a despertar de sua paráfrase de metrópole.

No cenário deste patamar de instintos subsociais, as massas coisificadas admiram e se espelham no status quo, buscando reproduzí-lo como status suposto de psicologia e de socialidade. Os farrapos que logra articular, mal servem para o seu desespero e sua ambição de alcançar o sucesso estrutural que não representam.

\section{A eficiência da dominação}

Mas por quê o culto do imediato? Por quê a crença de que tudo pode ser feito caso se acesse a tecnologia própria que permite fazê-lo? Não podemos nos esquecer que estamos diante da massa alienada, da massa desprovida do conhecimento de si, ou seja, da massa que é enquanto tal. Esta massa pronta para sofrer todas as manipulações dos grupos dominantes tem assimilado e ocultado a ideologia social das classes dominantes. Mede-se por ela e vê nela a solução dos seus problemas. No entanto, esta ou estas classes dominantes são fabricadas desde o exterior, pelas necessidades mercantis das metrópoles que as formaram. Semelhante entidade social do colonialismo carece de identidade própria, sua identidade é reflexa do pólo central, das classes dominantes das metrópoles. Em sua maioria, descendentes das classes subalternas nos países de onde vieram, estes grupos dominantes carecem de identidade brasileira. São meros capatazes. Mantém sua mentalidade subalterna em relação aos seus países originários, terras de "seus" avós, com sua superioridade civilizatória de fato mítica. Não podem romper com este mito. Sua ação, no espaço local, é recriá-lo. Trabalham aqui pela submissão da maioria às metrópoles. Nessa tarefa, distanciaram-se de lá, mas não se aproximaram daqui. Por isso, seus motivos são exteriores. Como o "inglês na Índia”, desempenham um papel civilizatório e carregam o "fardo do homem branco". Transmitem constantemente para o interior da neocolônia, os impactos dos efeitos-demonstração do funcionamento das metrópoles, sem lograr produzir algo diferente de colonizados mentais. Seus grupos dominantes reproduzem criaturas do neoconsumismo, vegetais caminhantes e urbanizados, atomizados e desprovidos de ação política consciente. Tais indivíduos professam um ajuste automático às exigências do poder, de cuja burocracia são temerosas correias-de-transmissão.

Existentes dentro de um contexto de poder, onde a linguagem só aparentemente é racional, devem os indivíduos desta sociedade fazer a defesa aparentemente racional do lugar de suas particularidades. Nesse sentido, politicamente, é aqui onde o negro se insere. O seu procedimento diante dos mecanismos do poder local não pode ser outro. Cabe ao 
negro nesta sociedade criar para si o seu privilégio, qual seja, obter um lugar específico baseado na sua particularidade.

Nas condições de um Estado parafascista, o negro deve buscar eliminar a particularidade dos atos do Estado praticados contra si, atos de exclusão política, de opressão e de injusta distribuição. O negro tem sido o judeu do nazismo brasileiro. A ele são apresentadas todas as contas, todas as parcelas de custo. O Estado brasileiro finge não saber que a raça negra não é uma naturalidade, mas uma relação social. Enquanto relação social, ela é o elemento sustentador da exploração, porque todo êxito não-negro está alicerçado sobre a exploração do negro. A hipocrisia analítica da ciência social oficial brasileira consiste em não perceber o capital como a exploração preferencial dos negros, como a captação de sua mais-valia, como a construção de um lucro adicional sobre cadáveres negros. Por outro lado, a sobreexploração dos negros permite viabilizar para a população branca uma redução de suas jornadas de trabalho e a perpetuação de que explorem mercados primitivos locais, constantemente reconstituídos pela esfera pública. Veja-se o aberratório dos menores infratores, dos catadores de lixo e das empregadas domésticas.

No sistema brasileiro, os negros não são apenas destituídos de todo; a engrenagem os torna disponíveis para destituir de novo; são submetidos ao controle psicológico e emocional. Na rede institucional, são desprovidos de papel próprio, de aprumo, de orgulho e de destinação positiva enquanto grupo. Tendo a sua identidade cassada, qualquer resistência os leva à condição de bodes-expiatórios perante as ações repressivas.

Infelizmente - apesar da parolagem pragmática do Estado - não existe uma tecnologia disponível para cada problema, muito menos no nível dos problemas sociais. A estrutura mitológica da moralidade privada não pode permitir que se constituam na sociedade núcleos de discussão aberta para a sua reforma, ainda que tal levasse ao fim da identidade esquizofrênica e, consequentemente, da inteligência minguante do poder. A opção dos grupos dominantes é sempre aquela pela negatividade de si. Não querem se enxergar, nem aprendem a sobreviver. Com a divisão destrutiva dentro de sua alma, tudo que logram é reproduzir tal divisão na sociedade. Confundem assim repressão com autoridade. Lutando para produzir um rebaixamento constante do horizonte político, os grupos racistas chegam a tomar medidas para exterminar as poucas conquistas do Outro, como a lei de estudo da África, o uso de atabaques em sessões religiosas e o livre direito de associação e práticas. Querem a eliminação de qualquer mancha negra. Querem uma sociedade ainda pior. A estratégia é intimidar, para obter a fragmentação crescente do 
Outro. Nesse caso, a ideologia da dominação usa a forma de seus oponentes para tornar-se eficiente. Recorde-se que na campanha eleitoral, o DEM-PSDB, que é a forma da direita hoje no país, usou rap, jovens negros, etc, para difundir suas imagens de simpatia, fazendo a fusão entre periferia e dominação. A forma das campanhas eleitorais da direita acompanhou tanto quanto possível as formas culturais circenses vigentes na periferia das cidades. Vê-se ali o poder corruptor dos grupos dominantes, ignorando e congelando os seus oponentes através de identificar-se formalmente com eles; silenciando outros candidatos, por via da justiça eleitoral; e esvaziando os programas de proposições, pelo ato de copiá-los e apresentá-los como seus. Esta atitude cínica não seria possível caso não ocorresse no cotidiano a despolitização banalizante, com que os verdadeiros interesses da maioria são "empurrados para a vala".

\section{Debate}

1. Gostaríamos de perguntar a respeito do conceito de poder que o senhor trabalha. $\mathrm{O}$ que é o poder e onde ele está situado na sua discussão teórica? Discutimos muito durante o curso os problemas da colonialidade, colonialismo e questões em torno de dominação e dominio, o senhor poderia comentar esses temas?

BARBOSA: O poder eu o entendo a partir das escolas historistas, que começam com a escola histórica alemã e recebem influência do materialismo histórico, do neokantismo. Entendo poder dentro da ótica das escolas estruturalistas e historistas, não do estruturalismo francês anti-histórico. Refiro-me à escola alemã, à de Cambridge e outras correntes que se difundiram junto com o marxismo no século XIX e XX. Dentro dessa leitura historista, as situações humanas se acumulam. Por exemplo, uma corrente com que simpatizo muito e uso na minha leitura é a Escola de Frankfurt. O pensamento da escola de Frankfurt é historista, porque as situações se acumulam. Se olhar para o problema do Estado com uma ótica funcionalista não-historista, não há acumulo. Por exemplo, a Segunda Guerra Mundial, todas as experiências históricas de Estado que se debatem durante e antes dela e que tem um desfecho, terminam na Segunda Guerra Mundial. O pósguerra constituiu outro cenário onde os Estados representam outras forças que politicamente começam a se formar na situação de cada Estado. $\mathrm{Na}$ visão historista isso não acontece. Por exemplo, na leitura da ala esquerda frankfurtiana ou do marxismo inglês, a experiência histórica do Estado não é interrompida pela Segunda Guerra Mundial e se acumula no pós-guerra. Marcuse em 1942, trabalhando com o serviço secreto norteamericano, fazia relatórios sobre a estrutura social da Alemanha e o fascismo, chamava ele 
a atenção de que, com o término da guerra, tal como ela estava feita, o partido nazista cairia do poder na Alemanha, mas, as formas nazistas e o fascismo se difundiriam pelo mundo todo. É como se estivéssemos combatendo um foco de vírus e a maneira de se combater o vírus contaminaria os combatentes. A sociedade do pós-guerra seria crescentemente fascistizante. Todo discurso da esquerda que veio do marxismo e do estruturalismo historista adota a tese da acumulação do mal. O mal não é uma virtude passageira da classe dominante que morreu no ano passado; é transmitida geneticamente para o novo Estado dirigido pelos seus filhos, netos, etc. O que é o poder da mídia? O que é a rede de satélites norte-americana hoje? É a vitória do Hitler! É o fascismo sem guerra. Evidentemente, pode promover guerras, tem esse poder, mas é o fascismo sem guerras. Não podemos interpretar, na visão dos estruturalistas historistas, a época contemporânea sem levar em conta o que a rede de satélites transmite através da TV a cabo - é a ideologia hitlerista sem guerra. Ou seja, eles aprenderam, estudaram, sofisticaram e aplicam nas massas do mundo todo aquele anestésico, aquela pasta anestésica, que são centro e trinta e tantos canais. E nós absorvemos aquilo sem um vínculo direto com o Estado. Mas, o discurso de cada Estado, seja do centro seja na periferia, é afinado com o discurso da mídia. O que representa a mídia? Ela representa domínio e acumulação. Se tirarmos a acumulação, ela não tem sentido. Ela representa o quê? $\mathrm{O}$ poder dos oligopólios, a impossibilidade dos oligopólios alemães ou italianos de ganharem a Segunda Guerra Mundial, ou os japoneses, se concretizou na vitória dos oligopólios que os venceram. E esses estudaram e aplicaram as técnicas, a sofisticação, a coisificação, o pragmatismo dos perdedores, que era mais avançado que os deles. Então, o mal se aperfeiçoou. Ao invés do mal ser derrotado na guerra ele foi aperfeiçoado. Uma vez que o vencedor copiou tudo que não prestava do vencido, que era mais sofisticado que ele, e passou a usar em escala de massa. O controle das mentes das classes sociais inferiores e dos grupos étnicos subordinados era o sonho de Mussolini e de Hitler, certamente também de Hiroito. Mas eles perderam a guerra. No entanto, os vencedores - acumulando a experiência histórica de fascistização - impuseram ao mundo todo um novo colonialismo que não necessita do desembarque formal de tropas para exercer o controle local da divisão do trabalho. Eles enviaram a Angelina Joli, o Brad Pitt, a Madonna e a Sharon Stone, eles enviam a imagem de Obama, e o controle é ainda mais sólido. A despersonalização da cultura local permite falsear a identidade local e tomarse ali o alheio pelo que é próprio. As instituições, como as pessoas, são seres históricos. Elas são uma produção acumulada da experiência humana, que só existe em sociedade. $\mathrm{O}$ Estado é um ser histórico. Como tal, ele acumula e expressa as experiências de dominação, 
as técnicas de sujeição e de destruição do Outro. Por exemplo, o pau-de-arara foi utilizado contra os escravos. Hoje ele é usado nas delegacias ou contra os adversários políticos do Estado. Ele não pode mudar, senão ao longo de muitas gerações e viragens radicais de costume. É ilusório acreditar que cada geração só traz a experiência dela mesma. Ela também incorpora a experiência anterior.

Chega-se ao Bush que é o Hitler sem qualidades. O Hitler tinha talvez algumas virtudes, o Bush não tem virtude nenhuma. O Hitler, por exemplo, era vegetariano. $\mathrm{O}$ Bush nem isso; é fazendeiro de bois e comedor de carne. A visão que estou colocando é estruturalista, herdeira de Frankfurt, do marxismo e da escola histórica alemã. É uma visão de historiador onde as coisas se acumulam. A leitura da periferia ou do centro só pode ser feita com a visão historista. As informações se acumulam se não, estaremos "no melhor dos mundos". Porque estaremos com uma rede de satélites que abarca o mundo todo, derrotando o Islamismo, logo essas emissoras além de transmitir o Homem-Aranha, poderão transmitir programas científicos e seremos regiamente educados, nossos filhos e netos, de tal modo que nem precisarão ir a escola, etc. Essa é a leitura liberal, que decorre do a-historicismo. A condição da colonialidade expressa os atos da participação política individual no mundo dos colonizados, ou melhor, dos pós-colonizandos. No ambiente da sociedade pós-industrial, num mundo em que as fábricas se fecham e o desemprego se torna galopante, você deve abjurar da sua identidade e assumir a identidade do vencedor. Deve identificar-se com ele. É o "se não pode vencer, vamos aderir". Você deve colonizar a si mesmo, para poupar o desgaste da metrópole. É por isso que - dentro de uma visão em que as experiências se acumulam - se trata de dominação e de domínio e estas categorias podem referir-se às piores experiências de extração da alma dos povos estruturados enquanto "Outro". Agora aquela que decorre do historicismo é uma grave, do perigo, da imbecilização fascista da multidão. Como por exemplo, a vitória do Kassab para prefeitura de São Paulo, que é só uma amostra grátis do que está a caminho. Não tem limites do processo de fascistização. A remoção dos direitos dos trabalhadores - nós insultamos os fascistas, mas vou citar algo "bom" deles, direito dos trabalhadores - quando digo que é pior que o fascismo é adotando só o que ele tem de ruim, a remoção do direito dos trabalhadores. O Mussolini perto do governo brasileiro era uma mãe ou um pai, porque permitiu sindicatos, sindicatos conjuntos patrão-empregado, os sindicatos já tinham representação automática com câmara nacional. Não precisavam nem de ser eleitos, todo sindicato tinha direito a um representante lá e tinha direito, portanto, de aprovar ou reprovar propostas de leis, vindas do próprio Mussolini até. Então, comparado com o 
nosso sistema, em que há muito só os direitos dos trabalhadores são removidos, nós temos o "custo Brasil". Temos um "entulho populista". Vemos aí que o liberalismo pode ser mais sombrio que o fascismo original, enquanto geração própria. Porque o fascismo original pelo menos para a sociedade que se fascistiza continha elementos de racionalidade, de pragmatismo, de assalto ao poder e de pseudo-revolução. Aqui tira-se isso e se fica só com a técnica de exercício do poder, para aplicá-la em outro lugar, onde não houve essa rebelião das massas contra o poder industrial, a coisa pode se tornar pior. É exatamente o nosso caso, vivemos numa sociedade que antes de chegar ao apogeu do poder industrial, o industrialismo foi desmontado e nós desembocamos numa sociedade pós-industrial, em que só tem renda uma minoria e os outros devem se virar para ter renda. Todo o discurso está voltado contra os outros. Particularmente contra esse outro que é o negro. É claro, caso se faça a leitura, literalmente não está voltado. Mas caso se leia nas entrelinhas, todo discurso está voltado contra o negro no Brasil. Ele é o portador do atraso, é o narcotraficante, etc, tudo que é negativo, é o favelado. Nada disso se acumula? É claro numa cultura, leitura, sociologia, numa história onde as coisas não se acumulam você é o responsável pessoal pela sua situação. Se você se desempregou não me venha falar do mês passado. No mês passado você estava empregado. O que aconteceu do mês passado para cá que você se desempregou? Essa é a linguagem funcional, a-histórica. Aconteceu que você cometeu algum erro, fez alguma coisa que perdeu seu emprego. E qual é a solução pra isso? A solução está aqui no jornal, "governo foca na educação", diz o ministro Edson Santos. Diz que "governo investe em educação para diminuir desigualdades entre profissionais negros e brancos”. É a mentira clássica do capital. Não tem nada que ver "estar empregado" com "educação", não tem nada a ver possuir emprego com o grau de tecnificação. É a impostura tecnocrata que diz aqui, a massa é levada a se convencer que existe uma solução tecnocrata ou tecnológica, para cada problema que existe. Os problemas sociais não têm solução tecnológica, não existe isso. Você não sabe como resolver tal problema, se ele é social. Você só resolve o problema de máquinas com tecnologia, não se resolve problemas de pessoas com tecnologia. Ao contrário agravam-se os problemas de pessoas com tecnologia. Principalmente, se a tecnologia for apropriada privadamente num horizonte de monopólio, de oligopólio, de poder étnico, é pior ainda. Quanto mais tecnologia sofisticada você entregar para a classe dominante no Brasil, mais negro desempregado se terá. Não tem solução. Bom, mas se ele quer explorar o negro, como ele desemprega o negro? Ele desemprega um negro e emprega outro para caçar aquele que está desempregado, como bandido, etc. Os serviços de segurança privada já têm 
dois milhões e meio de trabalhadores e, segundo o governo, $70 \%$ deles são processados na justiça comum, não tem condição de exercer legalmente a função de membros de uma segurança privada. São processados na justiça comum como criminosos. Quando se fala em fascismo é isso. Isso é a SA, a SS. Esse é o Estado fascistizado. Agora, o Estado fascistizado não quer dizer o governo fascistizado. Porque o governo é a parte do Estado que você elege, escolhe, e, evidentemente, ele é como a tampinha da cerveja, não dá nenhuma garantia do que está dentro da garrafa. Você pode trocar a tampinha à vontade, como essas nossas garrafinhas de água mineral. Eu tiro a água mineral de dentro, bebo, ponho querosene e troco a tampinha. A tampinha não dá nenhuma garantia se você tem água ou querosene aqui dentro. Então, essa é a leitura estrutural do Estado. Ela abarca todo o processo.

Se vocês observarem o Estado brasileiro, eles montaram a Ditadura de (19)64 que durou formalmente até 1985 e informalmente até 1990, quando o Collor tomou posse. É muito tempo. Não houve um juiz aposentado. Não houve um general aposentado. Não houve um oficial do Exército ou de outra Força que foi removido de sua função, ou da Aeronáutica ou da Marinha. Nenhum foi removido da sua função. Ninguém extinguiu o Cenimar, nem o CIAR, nem o Serviço Secreto do Exército, nada, nem reformou. Se você for exilado e se dirigir a um desses órgãos de acordo com a Lei de Anistia e pedir um certificado que você foi acusado de tal ou tal ato eles não lhe dão mais esse certificado. Eles se recusam a lhe dar. Baseado em que autoridade? Esse é o Estado brasileiro. Um Estado que sequer passou por uma pintura na fachada. É como pegar uma viatura da polícia e ir num centro de reforma infantil, e dizer: "queremos aqui os seguintes meninos, fulano, beltrano". Aí lhe dizem: "mas, eles não podem ser levados numa viatura da polícia, devem ser levados numa viatura da fundação Casa”... “Oh, cara, não conversa que nós estamos com pressa"... é isso. O Estado brasileiro. Nem sequer deram uma mão de tinta no Estado. "Aqui não é mais o Exército, agora é a Força de Defesa Nacional". Nada, mudaram nada. Não removeram uma pessoa. Do ponto de vista político, os racistas se esforçam por manter seu controle sobre o conjunto do Estado e - em períodos eleitoralmente desfavoráveis - buscam separar as esferas do Estado da esfera do governo, usando o Estado contra o governo e ignorando em proveito próprio a autoridade governamental. Esta forma de atuação dos racistas fica bem característica nos conflitos com os indígenas e na questão das quotas na universidade; como se sabe, foram adotadas quotas para pobres que em parte contemplam também o negro e o indígena. Os racistas procuram desmontar ou avacalhar as instituições tornadas democráticas, como as escolas públicas, as 
universidades públicas, etc. Ao mesmo tempo, levam os recursos públicos para financiar as redes privadas similares, apropriando-se desta forma de recursos que não seriam seus. Assim, em pleno século XXI, persistem os monopólios da educação, do lazer, da saúde, da terra, do teto, etc. No Brasil não aconteceu uma mudança. Não existe um democrata que diz: "eu não quero esse sujeito na folha de pagamento do Exército"; "eu não quero esse indivíduo na Polícia”. Lembram-se da DEOPS que ficava ali perto da antiga rodoviária? Sabe onde funciona agora? Na Polícia Federal, ali em Higienópolis. Se você pudesse entrar no site da Polícia Federal veria que tem lá departamento de Polícia Política. Deixou de ser um órgão estadual e passou a ser um órgão federal. O Estado não sofreu nenhuma reforma, é o mesmo Estado repressor da Ditadura. E isso demonstra a natureza anti-social desse Estado. O Estado brasileiro é para-fascista, porque os mesmos fascistas que o dirigiram na Ditadura continuam dirigindo o Estado na suposta ordem democrática. O que existe de democrático? Elegem-se vereadores, deputados, prefeitos, senadores, etc. Mas, esses vão exercer o poder executivo e legislativo. A autoridade deles não se estende a outros órgãos do Estado. Citarei um exemplo: houve a querela da Raposa Serra do Sol. Houve um general que tem comando na Amazônia que manifestou uma crítica ao governo federal. Estava fora do RDE, portanto. Declarou que havia ONGs demais no Roraima, que as ONGs estavam invadindo a Amazônia. Ele tem um canal interno para fazer tal comunicação, mas preferiu a mídia. Ele foi com um outro chefe do Exército até a TV Bandeirantes. Lá ambos “explicaram” à população que o Exército não está subordinado ao governo. Para eles, o Exército faz parte do Estado brasileiro e como tal não deve obediência ao governo. Talvez deva obediência ao Estado. Mas quem seria o Estado? Dito assim, ninguém sabe o que é o Estado. Vou dar um palpite. Talvez seja a classe dominante. Os plantadores de soja, os usineiros de cana do falecido Proálcool, o embaixador dos EUA. Mais ou menos a turma que deu o golpe de 1964, a "gloriosa revolução redentora".

Caso eles não devam obediência ao Presidente da República, fica tudo explicado. Quem infantiliza os indígenas também bloqueia as políticas anti-racistas. Ou seja, vocês supostamente elegeram o presidente da República. Quando falo isso sobre o caráter do Estado brasileiro e situo o problema do negro diante disso, o problema do negro no Brasil é o problema do Estado brasileiro. Não é o problema do governo brasileiro. As forças que tratam o negro como o tratam são invisíveis. Porque que o negro deve ser exterminado? Porque que a PM tem que matar negros? Porque trazem um secretário de segurança do Rio Grande do Sul para matar negros no Rio de Janeiro? E compram helicópteros que combateram na guerra do Vietnã para atacar as favelas do Rio de Janeiro? Qualquer dia 
trarão um Apache daqueles que operam no Iraque. Não trazem talvez, porque com dois ou três apaches os policiais dentro superariam todo o exército que tem o Estado do Rio ou de São Paulo. (...) Quem tomou essa decisão genocida? Só tem população civil ali na favela. Como é que eles não podem desarmar aquela população civil? Mesmo que tivesse que desarmar favela por favela, eles podem. Podiam subir lá, tomar todas as armas e dar um "papel de recibo". Não. Sobrevoam e metralham, jogam bomba e matam. Quer dizer, tem alguma coisa diferente. Trata-se de uma exclusão consciente.

O problema do colonialismo. O Colonialismo é aquele ser que conhecemos explícito. É o inglês de botas, desceu do navio, olhou em torno... Vocês viram o que eles fizeram na China, na Índia. Não fizeram aqui porque já éramos colônia do Portugal. Então, os indianos sofreram. Então sofriam aqui, os negros. Sempre com doses "homeopáticas", porque o poder bélico de Portugal era reduzido. Então, o que é a neocolônia? A neocolônia é a colônia que administra a si própria. Você já criou dentro dela uma classe dominante local, tanto quanto possível etnicamente estranha ou quase estranha. Ora, não preciso descer a detalhes sobre isso, vocês conhecem o Brasil. Nós sabemos que o Brasil é uma neocolônia. Como é possível o indivíduo ir viajar com um passaporte do Mercado Comum Europeu e outro passaportezinho do Brasil? Um não conflita com outro? Não, se um apenas for nação e o outro não for. Evidentemente, o Brasil é que não é uma nação. Eu queria que me indicassem quem nasceu no Brasil e é ministro em que país do mundo. Só no Brasil. Mas, nós temos ministros, diretores de área do Banco Central, da Receita Federal que são estrangeiros. Não vou me pronunciar sobre isso, porque é óbvio. Nós somos uma neocolônia. Temos um tratado de reciprocidade com Portugal pelo qual o português é brasileiro, mas lá somos parados no aeroporto. Se dissermos isso, "vejam esses ranços nacionalistas, ultrapatrióticos”! Mas não é disso que se trata. Trata-se de dizer que se fosse uma nação, ela teria direitos iguais a outra nação. E quem facultou mais direitos às nações estrangeiras? Os estrangeiros? Não fui eu, não trabalho no Itamaraty e não emito passaportes. Se eu apresentar um passaporte no aeroporto vão perguntar: para aonde o senhor vai? Vejam, não exiba dois, exiba um, o brasileiro. É uma má escolha que eu fiz. A polícia federal é do governo. Eu já fui detido pela polícia federal no guichê do embarque, porque eu estou condenado a ser brasileiro. Não foi porque eu estivesse "condenado", mas certamente por "parecer" brasileiro. Isso é uma condenação. Mussolini usava esse termo. "O indivíduo está condenado a ser etíope". Ele usou essa expressão, "não podia fazer nada pelos etíopes porque Deus os havia condenado a serem etíopes”. Não foi ele. Só que Mussolini era anarquista de origem, portanto ele não acreditava em Deus, era uma piada 
mesmo. Temos aqui a piada de sermos condenados a "ser brasileiros". Quem pode, leva outro passaporte. Quem pode leva um passaporte que realmente tem um conteúdo político. Então, é neocolônia sim.

"Dominação" e "domínio" são categorias diferentes da categoria "hegemonia". A dominação é uma categoria weberiana, mas antes de Weber, é uma categoria durkheimiana. O que o Durkheim queria dizer com dominação? Ele quer definir uma situação em que não há flexibilidade no sistema de poder. Existe uma cultura que deixa tudo rígido daquela maneira. Exemplifica-se com a sociedade medieval. Na sociedade medieval, não existia uma hegemonia dos senhores feudais, existia uma dominação. Porque você podia escolher "eles ou eles". Não tinha alternativa. Então, Weber discute e valoriza a categoria. Como nas condições da sociedade industrial, a burocracia mais os proprietários constituem uma amálgama irremovível por quem não é da burocracia e nem é proprietário. Esse conceito de dominação é utilizado para as sociedades onde não existe verdadeiro jogo democrático. Onde o mercado industrial não removeu as barreiras de classe do poder. Onde não existe a chance de um movimento que não é inspirado nos dominadores ou na "elite governante" alcançar o poder. Ou por extensão, onde não se consegue - mesmo que exista um processo democrático - a profundidade de um processo democrático. Por exemplo, em um sistema em que se elegesse um governo e ele não conseguisse alterar o Estado, ou modificar práticas do Estado, o que existiria seria uma dominação. É o caso latino-americano, o brasileiro. Podem-se eleger quantos governos quiser, no Brasil não vai modificar nenhuma prática fundamental do Estado. Vai continuar fazendo o que sempre fez; quem comanda o Brasil é a burocracia de instituições governadas por famílias que são as mesmas que governavam já no século XVIII. Podem-se levantar os nomes, fazer a lista delas; a esses nomes se acrescentaram mais alguns daqueles que vieram depois de 1880, mas, não que isso flexibiliza o poder. Nós temos um poder judiciário em que nenhum setor dele é eleito pela população. Imagine isso numa democracia, as pessoas não poderem votar num juiz. O juiz não é um advogado? Os advogados não são candidatos a determinados cargos em que a gente vota? “Ah, isso não, vai conspurcar a justiça!” Uma parte da justiça não pode ser conspurcada? Não pode ser conspurcada pela massa? Não, só pela elite. Está no jornal de ontem, no de hoje, a conversa entre os policiais federais, uma gravação apareceu agora. O subdelegado Protógenes teria falado para o diretor da polícia federal: "Não, o Dantas é carga pesada, porque eu fui ao escritório dele para intimar e ele tinha dois desembargadores e um juiz em função, sentados lá para receber a intimação”. Ou seja, ele - o acusado tinha à sua disposição dois desembargadores e um juiz, no escritório dele. Segundo a 
declaração do então delegado, havia um. Até um ministro do supremo tribunal estaria sendo indicado como interessado em um processo em que ele arbitra. Haveria um preço para manter solto o acusado, porque de fato é dessa hipótese que se trata. Não foi arranhado em princípio o poder do senhor juiz. É que o senhor juiz teria arbitrado um preço por telefone. Ele é apenas suposto ser um membro do Supremo Tribunal. Ele sapateou e os que o acusariam fugiram todos. Do governo que vocês elegeram são os que fugiram. Não é esse juiz, que ninguém elegeu que fugiu. Evidente, suponha caso ele fosse realmente do Supremo, indicado por um presidente qualquer. Nós o elegemos? Não. Está certo ele vender decisões? Não. Porque um presidente então o indicou? Quem mandou o presidente escolher com o dedo "esse aqui”? Então, a nossa situação é muito grave. Não é uma democracia e sim, dominação mesmo. Temos classe dominante e grupos dominantes. Os juízes deveriam ser eleitos, para expressar a sociedade. Razão até porque uso na minha fala "classes dominantes". Porque o Brasil não tem uma classe dominante só. O latifúndio continua. Temos uma burguesia industrial. Uma alta burocracia, que desde o Império português só fez se ampliar. Ministros do governo português que administravam daqui o Império. O Império português foi embora e deixaram a burocracia aqui para administrar o Brasil. Como diziam os gaúchos: "é o governo português do Rio de Janeiro". O Império do Rio de Janeiro, que era um lugarzinho pequeno com uma estrutura burocrática imensa, sugando toda a mais-valia que o país tinha então e repartiam entre eles. Imaginem hoje um juiz que ganha 30 mil por mês, um coronel da PM que recebe de aposentadoria 47 mil por mês. Eles são da classe dominante, porque muita gente da FIESP quer tirar 47 mil limpos por mês. O coronel da PM é mais da classe dominante do que aquele empresário. É mais proprietário e mais capitalista. E tira isso com uma "canetada" dada por um juiz qualquer. "Ele tem direito a incorporar porque, nesse caso, são todos partidários da acumulação histórica". Os fatos passados descarregam-se sobre os fatos presentes. Porque quando ele era aluno na escola, como cabo e sargento, já estava servindo. Então, isso dá a ele um benefício, mais retroativo, vezes tal, no fim. Os militares contam o tempo que eles estudam no ginásio para a aposentadoria deles. Qualquer militar de 50 anos que queira está aposentado. Nós também não fizemos ginásio e colegial? Dizem que a dele é uma escola militarizada, então estava "dando serviço". Vocês acreditam nisso? Acho que não.

2. É verdade que os militares não podem votar?

Os militares não podem votar porque devem ser neutros. Só os oficiais podem. Se votarem, irão formar - supõem-se - um partido. Só os oficiais votam. Eles servem ao Estado. Se houver um conflito em uma câmara de vereadores, os praças iriam estar 
divididos em "oliveiristas" e "pereiristas". Então, essa é a razão porque "os militares não votam”. Até certa patente, dali pra cima votam. Por exemplo, na Constituição de 1946 sargentos votavam, mas não podiam ser eleitos. Por quê? Porque um oficial poderia se candidatar e o sargento ser mais votado que ele, seria uma humilhação hierárquica. Teve um sargento no Rio de Janeiro que teve 35 mil votos para deputado federal e houve muitos generais que se candidataram e não foram eleitos. "Não se vai dar posse para esse sujeito". Gerou-se assim aquela rebelião de Brasília. Os sargentos tentaram tomar Brasília. Então, só oficiais são militares, os outros não são nada. De aspirante a oficial para cima é-se sujeito, dali pra baixo não se existe.

3. A Folha de São Paulo é anticota. Pensando esse discurso ideológico de genocídio da classe dominante, como isso funcionaria nessa administração? E também gostaríamos que o senhor comentasse sobre o uso que faz do termo negro e relações raciais e, em outros momentos o senhor fala sobre relações étnicas. Qual seria a diferença entre eles nas ciências sociais? E o conceito de casta?

O problema do genocídio. Tem um filme de um daqueles jovens cineastas do Rio de Janeiro, Notícias de uma Guerra Particular, nele um delegado, que na época era chefe de polícia no Rio de Janeiro, do PT, Hélio Vígio parece, ele coloca essa questão do genocídio. É impossível ser mais perfeito do que ele foi. Ele mostra com o problema do espaço, como o negro está circunscrito ao espaço da favela. Quando D. João regente chegou ao Brasil, o susto que os nobres portugueses tiveram é que toda a cidade pertencia aos negros. Foi então que se criaram os esquadrões da morte. Punha a hora limite de dez horas da noite para os negros estarem na rua. Quem estivesse depois desse horário, eles atiravam. Trouxeram um batalhão de irlandeses, outro de alemães e botavam na rua. Então, os capoeiras iam enfrentar aqueles indivíduos. Todo dia, à noite, tinha um conflito na cidade. E de manhã havia meia dúzia de mortos, outros puxando pela perna. Então, o esquadrão da morte começou assim. Comemoramos este ano "esse ganho civilizatório" que D. João VI nos trouxe que foi "desnegrizar" as ruas do Rio de Janeiro. Qualquer coisa que possamos dizer sobre o genocídio está dito naquele filme. Se vemos aquele filme, vê-se o que é o genocídio. E como a população pobre é empurrada como bode expiatório para uma área de resistência física. Eu compreendo que a mulher negra não entre nessa. Mas o homem negro, rapaz, jovem que tem testosterona em excesso como qualquer outro elemento masculino animal, ele não agüenta. É uma reação normal de o macho encurralado tentar resistir. Então, a percepção é feita nesse nível biológico. A condenação do negro ao espaço da favela, ou seja, a favelização como instrumento aculturador, leva ao perigo do 
apartheid total, desde o espaço geográfico ao espaço cultural. Semelhante absurdo só pode ser enfrentado pela elaboração de estratégias anti-racistas. A escola, por exemplo, deve ser desracionalizada pela superação de suas barreiras econômicas. Assim, quem fala em raça pode de fato lutar pela desrracialização.

Um negro assim como eu que sou do Rio de Janeiro de origem, as preleções que eu ouvia da minha mãe eram para não resistir. O negro sobrevive por mero acaso, porque sua atitude é simplesmente temerária. Ele vai a qualquer lugar que quer, faz o que quer. Vai dançar, passear, em qualquer lugar. E a filosofia é, na hora de morrer, ele vai morrer como macho. Isso tange a massa negra para ser vítima do genocídio porque são ou estão encurralados. É o mesmo que matar boi em matadouro. Encurralados e levados a resistir para serem exterminados periodicamente. Podemos ver isso na pirâmide da população negra e podemos ver isso na família negra, onde o elemento masculino sempre está ausente. Está ausente porque está morto.

Porque relações étnicas? Relações étnicas porque no movimento negro nos anos19(80) havia muita discussão não como relações raciais, mas étnicas. Isto porque, se pegar o negro no Rio de Janeiro, em São Paulo, no Rio Grande do Sul, em Minas Gerais, etc ele tem ou teria uma diferença de um lugar para o outro. Essa diferença dá ou daria uma peculiaridade. Ela faz que, embora todos os negros falem a mesma língua, o negro seja muito mais facilmente localizado como uma etnia do que como uma unidade no país inteiro. Então, de fato, o poder do Estado, se relaciona com negros mineiros, cariocas, gaúchos. Mas não se relaciona com negros brasileiros, porque nem ele quer se relacionar, nem os negros têm uma estrutura institucional nacional. Aí vemos predominarem as relações étnicas. Bases locais. Pessoalmente, acho que mais homogêneo que o negro brasileiro nem o branco é. O negro brasileiro é mais homogêneo que o branco brasileiro. Mas, para não ser "o gravata de couro que não segue a boiada", sigo a boiada e falo em relações étnicas também. Agora, qual o conceito de raça do movimento negro? Também nos anos 1970 e 1980 foi muito discutido o problema da raça. A raça para o movimento negro é uma categoria política, quer dizer, a sociedade estabelecida discrimina o negro no grau da sua escuridão. Quanto mais escurece mais discriminado ele vai ser. Podia-se fazer uma tabelinha com as línguas estrangeiras que ele deveria falar para diminuir um grau de "negridão da negritude dele". Se ele fala francês desconta $10 \%$, se inglês mais $10 \%$, alemão $15 \%$ e assim sucessivamente até ele ser tratado como branco. Oh, doze línguas, o cara é gente! Essa obscuridade do negro é presencial. Quando o negro chega, ele já está identificado. O judeu evidentemente tinha aquela maquininha do Hitler que os identificava, 
tinha uma agulha que tremia. Outros identificavam pela aparência, cabelo enroscado, é judeu. Quanto ao negro não, entra na fila da empresa com a carteira de identidade na mão, o patrão já sabe que ele é negro. Ele não está preocupado com a "condição étnica", se é gaúcho, maranhense ou mineiro, já o identificou. Quando mais escurinho for, mais identificado está. Enquanto mais branquinho, menos. Então, o movimento negro se debate com o fato: o negro existe. Mas oficialmente, nos anos (19)80 as raças não existiam. O conceito de raça tinha sido destruído pela biologia. O que os brancos fizeram? Se olharmos a antropologia dos anos (19)70 no Brasil simplesmente foi desracializada. A pesquisa sobre o negro continuou, porque todo o organismo morto deve ser pesquisado. Tudo que está morto deve ser dissecado. Então, continuaram desmontando o negro, mas só como reminiscências, fatos do passado. O movimento negro atrapalhou isso. Primeiro porque o negro que ele tratava não estava morto, era o negro que estava vivo. E, segundo, não era o negro que era mulato, ou moreno, ou jambo, ou chocolate, era o negro que era negro. Eles até discutiram: vamos nos chamar preto ou negro? Eu votei pra ser preto, perdi. Negro ganhou, agora você é negro! O grupo que assumiu "eu sou negro", trouxe a raça de volta. E no jornal do movimento negro raça são os negros do movimento negro, movimento político-social, quem se considera negro, e negro significa também um espaço político cultural que é a negritude. É uma reflexão sobre o que é ser negro no Brasil hoje. Isso é um ato de desafio ao Estado. Não é desafio a nenhum governo, mas ao Estado, que durante centenas de anos trabalhou pela diluição absoluta do negro. Instruiu o negro: "desapareça, vá embora, suma". Hipnotizou o negro para ele desaparecer. E de repente esse grita: "não, eu sou negro!" Ih, cara inconveniente, não há nada a fazer com esse indivíduo, largue-o a sua própria sorte! E o negro aparece reivindicando: "eu quero escola, eu quero indenização!” Então, o negro, a raça são condições políticas. Qual a definição que o movimento negro dá no Brasil a "negro”? Negro é aquele que se declara negro. Eu posso me declarar "negro" porque meus avós são negros, ou porque nasci no meio dos negros. Nós temos esse problema no Brasil, grande parte dos portadores da cultura negra no Brasil não são negros, etnicamente falando. São brancos, mas eles vivem no meio do negro e a cultura que têm é a do negro. Isso também o movimento negro fez nos anos 70 e 80, identificar a cultura negra. O primeiro deboche que o negro ouviu ao dizer "eu sou negro, viva a raça”, foi: o que é "ser negro"? Eu cansei de ir a mesas em que os antropólogos me perguntavam: mas, prof. Wilson, o senhor que é tão polêmico, o que é ser negro? No que o negro se distingue do branco no Brasil? E eu dizia: a primeira coisa por ser brasileiro. O único brasileiro que existe é o negro, todos os brancos não são brasileiros, o negro já está 
condenado a ser brasileiro. Essa era a provocação maior de todas. Provar que o estrangeiro no Brasil é o branco, porque é o único que não pensa o Brasil como uma nação. Se pegar qualquer negro ou mestiço no meio da rua, ele pensa o Brasil como nação. Ele pensa que o Brasil existe. Ele está convencido disso. Mas o branco da classe dominante ele sabe que o Brasil não existe, é uma fazenda, um lugar onde se ganha dinheiro, onde se toureia aquela massa escura o dia inteiro. Quando o cara chega em casa diz: "oh, hoje o trabalho estava aquele inferno". Um monte de negros aparece na imaginação deles, os que ele tem que administrar. Só um momento ele se orgulha, quando chega um estrangeiro e ele exibe: "veja essa empresa é minha, veja como esses negros fazem exatamente o que eu os comando para fazer". E aí o estrangeiro fica com o olho na taxa de mais-valia que ele tira a mais ali que é a metade do salário baixo. O salário do país é baixo, dele a metade é paga ao negro. Então, o americano, o inglês e o francês ficam todos com o olho grande, numa inveja mortal. É o único momento de triunfo. O momento de humilhação é quando ele sai daqui e está na Sorbonne ou em Londres, e perguntam para ele: "você é brasileiro, feijoada, samba, Pelé?” Aí o olho dele vai ficando murcho.

O conceito de casta. Casta é uma unidade fechada que reparte a renda da sociedade por um critério pré-estabelecido, em geral, também de origem étnica. Por exemplo, no sistema de casta hindu, as castas são determinadas pelo ultimo vencedor. Se olhar o kshatra, a primeira categoria, o individuo que tem o monopólio da condição de ser religioso ou guerreiro, são os vencedores, eles que conquistaram. O degrau de baixo é formado pela antiga classe dominante que já existia. Quando quem domina se congela na casta, tem uma vantagem. Não se tem mais nenhum desafio, a não ser a revolução total. Mas não há nenhuma mobilidade ou dinâmica social para enfrentar. Porque quando se monta a casta, ela está fechada em si mesma. Evidentemente, a casta é mais duradoura se conseguir uma justificação moral. Pode ser do poder, como eram as castas assírias, ou política. Depende da força, ou moral como na Índia, que é religiosa. Então na medida em que os deuses determinaram a estrutura da sociedade assim, você se conforma com seu lugar na estrutura da sociedade. O desfecho das guerras é uma vontade dos deuses. Fica-se na sua casta e não se mexe nela. Um professor indiano: a família dele é de professores há dois mil anos. Um transportador de lixo, a família dele transporta lixo há dois mil anos. Isso gera não só uma diferença física entre as pessoas, como de mentalidade. Cada casta tem uma mentalidade diferente da outra. O sistema da revolução de Gandhi aboliu o sistema de castas, teoricamente. Mas as pessoas não saem da sua casta. Conheci vários indianos na Europa. Estudei com eles, eram quase todos da casta dos professores. Aí vê-se que não sai do 
sistema. Um desses indianos descendia de trabalhadores braçais, mas ele não veio da Índia, e sim da África do Sul. Fez faculdade lá, onde o sistema era mais aberto para os indianos entre eles, não em relação à sociedade sul-africana. Fez lá e foi para a Europa e conversava com os outros indianos da Índia. Mas há mais proximidade entre ele e um brasileiro, do que entre ele e os indianos. Não andam juntos, não tem convivência, mesmo não sendo hostis. Realmente estão fora do sistema dos outros. (...) A casta dos professores faz um enorme discurso sobre mudança, mas na Índia não representa nenhuma mudança. Quando o Ianni falava do sistema de casta no Brasil, o português trazia o africano e o colocava numa posição que correspondia ao interesse do português no Brasil. Então, se pegasse um africano de certo status social, ele dava uma posição, dentro da massa escrava, diferenciada em relação aos outros escravos. A massa escrava era homogênea do ponto de vista do português. Mas era heterogênea do ponto de vista dos escravos. Não era a mesma coisa ser escravo dependendo do lugar de que se vinha. Se chegasse num lugar em que houvesse muitos escravos da mesma região, certa estrutura social de lá se reproduzia aqui. É fácil entender. Vamos dizer que eu venho num navio, chego e sou vendido na Bahia ou Maranhão. Na fazenda que vou parar, há um indivíduo da minha mesma origem. Ele na minha sociedade era um príncipe e eu era uma pessoa comum. Evidentemente, devo tratálo como príncipe. Então, ele diz: "Wilson, estou cansado, pegue esse machado e corte aquela árvore para mim”. Eu digo: “Sim, senhor”. Iria lá e cortava a árvore. Nós éramos escravos. Para o português era tudo a mesma coisa, não absolutamente, porque ele explorava isso. Nós subestimamos o conhecimento que o português tinha da massa escrava, porque nós não temos, eles tinham. Mas eles falavam línguas africanas, viveram na África, iniciaram o processo de aculturação do africano em Portugal antes de construírem o Brasil. Então, por exemplo, vários príncipes da Angola e do Congo foram para Portugal, estudaram e foram educados lá e viviam no palácio real. Vemos a correspondência deles e tem-se: "Caro Irmão, estive em tal lugar e tal". Ele estava na África, mas como passou cinco ou seis anos convivendo com o outro quando tinham dez anos ou quinze, são amigos; e continuam se vendo como iguais. A correspondência mostra isso. Quem se sacrificava nessa situação era a massa dos africanos, não a elite deles. O português deliberadamente não vendia um príncipe como escravo. Os outros, africanos vendiam, mas se ele descobria tratava logo de minorar o mal, comprava o cara e o colocava trabalhando em um cartório ou num serviço urbano, tirava da situação do trabalho na fazenda, que era mortal. Trabalhava-se ali sem roupa e o cálculo de vida que lhe davam era sete anos. Depois de sete anos, o escravo já tinha se pagado e ao seu substituto, tudo que viria depois 
era lucro. O fazendeiro não estava fazendo questão dele estar vivo. Tem algumas coisas que esquecemos como verminose, tuberculose. A viagem no navio negreiro era um foco de contaminação tuberculosa. Então, a devastação nas populações escravas feitas pela tuberculose não fazemos nem idéia, morria-se feito mosca. Obviamente, se vivia na cidade, tinha outra oportunidade. Mas o grosso da massa escrava não era para viver na cidade, e sim, para o sistema de plantação ou mineração. O simples fato de ficar na cidade já era um privilégio que dependia do olho do senhor de escravo. Fazia uma escolha que tinha um componente étnico ou de simpatia pessoal que vem dar no discurso do "ladino e do boçal". O boçal era o escravo que o patrão falava e ele não respondia nada, só ficava olhando, era uma incógnita. O patrão não queria muito ver esse perto dele, sentia medo. Então, dentro dessa casta era praticamente impossível romper aquela situação. A situação em que se era jogado ia-se passar a vida toda ali. Os escravos da D. Carlota Joaquina eram dezoito, não eram dezoito mil. Ela ia e escolhia. Então, a massa escrava não estava nessa, chegavam mais ou menos quarenta mil por ano que eram vendidos e dezoito, poucos, era para uma casta fechada mesmo: escravos do palácio. O cara caia ali dentro e ficava até morrer. As duas maneiras de sair dali, reais, eram: morrendo ou se tornando imprestável. Se vivesse vinte e um anos, como escravo, produzindo cada vez menos, podia chegar lá na ponta, escravo há mais de vinte anos, pegar uma doença. O senhor então liberta você. Mas, não é libertar no cartório, aquilo era para uma minoria ínfima. Caso pegarmos todos os documentos em cartório que conhecemos, dá 4\% da massa escrava estimada. É “cai fora", mandava abrir a grilheta e dizia vai embora, dava um facão. Ele ia embora para o mato, ou morria ou se curava. Ou talvez tivesse inventado um chazinho. Parava de tomar e em três meses estava "zero bala". Então, a maior parte da população que gera o Brasil é formada por esse escravo alijado da escravidão, que perde o valor, o interesse econômico. É o que fica pelas estradas e caminhos. A tropa não se dava ao trabalho, quando mais se avança na colonização portuguesa, de prendê-los. Prendiam aqueles que tinham uma ordem de prisão. Não qualquer negro andando numa estrada. (...) Essa população ia para a barranca de um rio, se metendo nas aldeias dos índios, que recebiam os negros, e foi gerando a população brasileira, à revelia da produção escravista, da economia de exportação. É essa população que a gente não fala, mas são os primeiros brasileiros. $O$ individuo vivendo lá no meio do mato, plantando mandioca, abóbora, criando porco e longe da civilização. Quando começava a aparecer muita tropa naquela região, saíam eles de mansinho e iam para mais longe ainda. As rancharias eram poucas, por causa do interesse econômico do colonizador. Então, ele, o ex-escravo, nunca fazia vinte casas, era duas ou três. Lá mais adiante outras 
duas ou três. No meu tempo, os estudantes do secundário perguntavam muito para o professor e não recebiam resposta: "professor, se os índios tinham aldeias e os africanos na África tinham aldeias, porque no Brasil no campo não se tem aldeias, só se tem fazenda?” $\mathrm{Na}$ verdade é porque se fizesse aldeia atrairia repressão. A autoridade ia caçar e levaria uma tropa de vinte. Também não era maluca de levar quatro ou cinco soldados. Aquilo para eles não seria nada. Para o negro local, ele se defendia. Caso aparecesse o sinhozinho, perguntando quem era o dono daquilo ali, responderia: “ah, é senhor fulano, ele autorizou a gente a ficar aqui”. Ele não era bobo, se defendia. Assim, o senhor fazia de conta que acreditava naquilo. Modus vivendi. O que o negro fazia ali? Criava porcos, plantações e ia vender na venda dos portugueses. Ele sabia que estava sendo roubado, mas ajudava a validar a sua presença ali. Porque se ele mata um porco seu e vende para o português, pega ou compra sal, ferramentas. Está pago. Ele, o comerciante, vai querer que volte para vender outro porco. Foi essa a formação do Brasil nesse eixo que vem do Maranhão até São Paulo, descendo por Goiás. Do outro lado, da Serra da Barriga, até o interior de Minas Gerais. Havia uma mancha de escravismo organizado, economia exportadora e uma massa jogada lá dentro, no sertão. Evidentemente, tinha senhores que pegavam crianças para escravizar, sempre teve, o tempo todo teve. Mesmo com a proibição de escravizar o índio, eles o faziam. $\mathrm{O}$ índio mestiço com o negro, coitado, se condenava à escravidão. Mas, não era um fato generalizado. O fazendeiro menos pobre comprava o escravo que tinha papel, que vinha do mercado. Não ia para o meio do mato ficar caçando, porque sabia que arranjaria problemas. Quem conhecia bem a terra, o interior, era um problema para ele. Então, podemos ficar com essa idéia de uma sociedade fechada num patamar e dentro da própria massa escrava, vários papéis, degrauzinhos que era difícil, sendo escravo, passar de um degrau para outro. E isso, implicava sim, em diferenças étnicas, em rivalidades entre os escravos. Era mais fácil o indivíduo colonizador se relacionar bem com certos nigerianos do que com angolanos ou negros da área de Moçambique ou do Congo. Por razões que diziam ser "este mais civilizado", então se negociava. Acho que não era uma diferença de civilização e sim de cultura, em que uns são mais belicistas do que outros.

4. O senhor poderia comentar a eleição nos EUA, com a vitória de Barack Obama? Alguns alunos trouxeram uma informação para a sala de aula dizendo que Zumbi tinha escravos, gostaríamos que o senhor comentasse isso também. A respeito da opressão, que o senhor tão bem apresentou, gostaríamos de saber qual a margem de reação que podemos ter; estamos a dez anos tentando aprovar uma lei para introdução da história africana no ensino brasileiro, com problemas com a formação de professores, a mídia trabalhando 
contrário às cotas; então, como fazer com o discurso que existe? Como organizar uma reação?

A vitória de Barack Obama é muito importante porque reflete a união das forças democráticas na sociedade norte-americana. O perigo é a desilusão, como em parte se deu aqui com o governo Lula. Depois de eleito, é necessária uma permanente mobilização popular para que o eleito não possa se bandear, "com armas e bagagens" para a política conservadora e até reacionária da elite dos monopólios e oligopólios. Só uma nova institucionalidade popular pode garantir uma ampla mobilização.

O problema do negro nos EUA é o seguinte. A sociedade norte-americana é reformada, já na fundação dela. A sociedade reformada é baseada no individuo, não nas instituições públicas. É baseada na liberdade individual, no sistema institucional a serviço dos indivíduos. Os reformados criaram os EUA. Quando os escravos foram para lá, podese ver que a maioria dos proprietários de escravos eram não-reformados, católicos, etc. Os reformados sempre que assumiram os escravos, compravam os escravos, criavam um mundo dos escravos para os escravos. O que era esse sistema? Era outro, em vez de o individuo morar em uma senzala. Esta era o nosso modelo aqui - que é um termo dúbio, senzala originalmente é um túnel onde os negros são enfiados dentro -. Esse túnel fazia fronteira com o chiqueiro dos porcos, porque os negros defecavam naquela água que passava dentro da senzala, e aquilo ia para o chiqueiro dos porcos, e os porcos eliminavam aquilo. O convívio tinha um motivo, “ambos são porcos", rigorosamente. A casa grande está em cima, esse é o conceito luso-brasileiro de senzala - por extensão, quando os negros são postos para fora da casa grande, eles são deixados no Brasil para morar no morro, um morro qualquer da propriedade. E manda-se fazer os casebres ali, nunca na várzea, mas no morro. Porque com um golpe de vista o capitão-do-mato via tudo o que se estava passando no morro. Também o fato das choças não poderem se cercar, ficar uma próxima à outra, eliminava a criação de bichos. Não dá pra criar porcos onde não tem cerca. Então, só criavam um cabritinho no máximo, um frango. Era a ideação da favela, é a senzala a céu aberto, pega um morrículo põe "os seus pretos" todos lá, continua chamando de senzala. No entanto, cada um tem o seu rancho lá. Como é que o negro casava? Com a autorização do senhor. Sem a autorização não podia casar.

Nos EUA, o negro é posto a parte num rancho no meio da plantação, um posto aqui, outro ali, outro acolá. Eles são catequizados e as práticas africanas são proibidas. Não podia ser apanhado com amuletos africanos ou essas coisas, tinha que ser o reflexo da reforma protestante. Tinha que ler a bíblia e se reunir para isso. Se fosse reunir para ler a 
bíblia podia, para outra razão não. "Bater tambor" nos EUA dava pena de morte para o escravo. Então, o negro nos EUA, sendo uma minoria, foi projetado à imagem e semelhança do branco reformado. Por isso, iria ter a igreja batista dele. Mais tarde, escola em que o professor é negro e os alunos são negros. E terá mais tarde ainda colégio para fazer o secundário. Porque está separado do branco, a instituição dele pode ser igual a do branco. Mas está separado. Como aqui ele está dentro do sistema do branco, não está separado, não podia ascender ao sistema do branco. As duas pessoas que podiam pegar um negro no Brasil e fazer dele outra coisa era um padre ou um senhor de escravo. Um senhor ou sinhá podia dizer: "deixa esse negrinho aqui que eu gosto dele". Isso existiu, mas ao capricho do poder do senhor, não é uma saída institucional. Não existe nenhuma válvula ou janela que permita aquilo, é o poder absoluto do senhor que faz o que bem entender com a propriedade dele. Nos EUA, também o senhor podia fazer isso. Muitos deputados lá puseram o negro para estudar, mas o lugar normal do negro era na plantação, como empregado de serviços, só que a instituição permitia a duplicação. Se olharmos o apartheid da África do Sul é a mesma coisa. Porque eles separavam o negro, mas não o proibiam de abrir a sua própria igreja protestante, nem a sua própria sala de aula. Imagina aqui, o negro ir para o senhor e dizer: "eu posso abrir uma sala de aula?” (...) não poderia. Então, essa é a diferença fundamental entre o negro dos EUA e no Brasil. Sistema institucional, no Brasil prevalece o Estado, abaixo do Estado o proprietário. Nos EUA, é o regime do proprietário, o Estado é muito pequeno, não interfere na vida social a não ser praticamente nas vésperas da Guerra de Secessão. Ali, o Estado norte-americano se tornou suficientemente grande, e o conflito veio à tona para ele intervir na vida social. O que agrava? Agrava o número. No Brasil, o negro sempre foi a maioria da população, nos EUA sempre foi uma minoria. Então, lá não punha em perigo o sistema institucional norteamericano. E no Brasil o sistema institucional tinha que prever o lugar do negro. Tinha que legislar o tempo todo sobre isso. Tomar decisões. O Capitão Governador da Bahia autorizou os negros a baterem tambor primeiro três noites da semana, depois todas as noites. Por quê? Porque ele sabia que cada nação negra ia bater o tambor diferente da outra e ia reforçar as diferenças entre os próprios negros. Por que permite isso? Porque ele não tem um sistema institucional livre, forte o suficiente para levá-los todos para a Igreja Católica.

De tempos em tempos aparece esta estória de que Zumbi tinha escravos. Penso que isso é invencionice, não pode ser provado. Os documentos sobre Palmares são limitados e ainda assim representam a voz oficial do colonizador. Zumbi tanto poderia ter escravos - 
porque na África Negra havia escravidão doméstica - como podia não tê-los. Recorde-se que Palmares era uma série, nove ou dez, aldeias, com laços muito frouxos entre si, praticamente de defesa militar. Não era um estado estruturado do tipo colonial. Parece que ali vigia um regime de comunidade de bens. Se tal fosse, a escravidão não teria sentido econômico. E uma escravidão de poucos, sem sentido econômico, só poderia expressar uma forma moral, um castigo, uma espécie de punição por violação de regras coletivas. Observe o mesmo nas revoluções contemporâneas, são poucos os degraus punitivos que os estados embrionários - particularmente agrários - logram estabelecer. Isso porque não há polícia. Não há presídios. De pequenas punições, nesse caso, salta-se logo para a pena capital e não para a escravidão.

Não há a pretensão, mesmo nos séculos XVI, XVII, XVIII e XIX, do senhor de escravos, de dominar a cultura do negro. Pelo contrário, eles vêem a cultura do negro como um artefato da propriedade deles. Quando ele recebe visitas, chama os negros e diz a eles para baterem tambor a noite para a visita ver. E eles sentavam na varanda, os negros iam lá e faziam a sua festa para os brancos verem. Os negros ganhavam naquela noite cachaça, era uma noite de liberdade, para eles estava ótimo. O que é aquilo? É a demonstração da cultura européia da Bahia ou do Rio de Janeiro? Não. Ele está mostrando: “esses caras lá na África tem essa cultura ấ”. Quando a visita ia embora também perdia o interesse. Só tinha aquilo nos dias certos do ano que tinha direito à festa. (...) O senhor estava num mundo de negros. Para o norte-americano, não, o negro estava no mundo de brancos. Essa diferença é fundamental.

Fazer política é algo que o dominado não sabe fazer direito. Fazer política é algo que caracteriza a classe dominante. Ela se baseia na psicologia social de cada grupo dentro da sociedade para dar-lhe a entender que representa - ou está tratando - de seus, os dele, interesses. A classe dominante trata apenas do próprio interesse dela. No entanto, através de uma chuva de declarações, blá-blá-blá, decretos, leis, portarias, regulamentações, ela dá a impressão à maioria da sociedade que está ali para servi-la. "Eu sou um criado - vosso deputado - ao vosso dispor". Para viabilizar no plano das hipóteses tais promessas ela - a dominação - as media através da ideologia social e da ideologia política. Daí a enganação. Daí os equívocos. Daí o indivíduo-vítima entender o que quer entender e não realmente aquilo que acontecerá.

O movimento popular tem a pretensão de fazer política dizendo algumas verdades. A intenção é boa. Mas algumas verdades não são a verdade: são mentira. Daí dá-se duas 
maneiras de fazer política. Uma é bem intencionada. A outra trata-se de enganação pura e simples.

Há duas maneiras de se fazer política: (1) uma você engana as pessoas, malevolamente ou benevolamente, não quero dizer que a esquerda enganava por maldade. Não. Era a concepção dela, como aquele célebre discurso do Stálin que "você precisa dizer a verdade, mas não precisa dizer toda a verdade”. Essa é uma resposta do Stálin. É uma maneira de enganar bem intencionada. (2) a outra maneira no mesmo lado é dizer a verdade, fazer a política ideologicamente, a verdade que está a seu alcance, você diz. Por exemplo, é evidente que o negro no Brasil só vai sair dessa situação se ele se organizar, mas se fizer isso aos milhões. Não vai ser organizando cento e cinqüenta negros não. Nem mil e quinhentos, nem quinze mil, nem cento e cinqüenta mil. Quando se tiver um milhão e meio organizado começa "a apertar o sapato de gente por aî". E isso só passa por um movimento de organização política por negros conscientes da situação real da sociedade brasileira. Ora, se nós começarmos a enganar desde aqui o cara, já sobre a natureza do Estado brasileiro, que avanço essa pessoa fará? (...) Isso é um problema estrutural, é uma estrutura. Só se muda estrutura, mudando-a. Não há outro jeito. Agora, penso que essa estrutura pode ser frágil. É forte, porque é dialética, mas é frágil. Por que? Ela está alicerçada sobre a consciência da maioria. Se a maioria tiver outra consciência, ela rui automaticamente. É o mesmo problema do socialismo ou do capitalismo. É uma escolha do trabalhador. Marx diz: o socialismo é uma escolha do trabalhador. O trabalhador pode escolher criar um regime para ele. Ou não. Tem o "ou não”. Se quiser viver tomando "telefone" do patrão, o problema é dele. Marx também não ficava angustiado com isso, não. Se lermos O Capital não existe essa choradeira. É a mesma coisa que temos que fazer, não podemos enganar. Aqui, auto-enganar-nos seria conhecer os problemas superficialmente. Não posso dizer outra coisa a vocês. O que eu vejo é bonito? Não é bonito; é triste, horrível. É uma máquina montada para moer gente. Se perguntarmos ao deputado A ou para o presidente B desta ou daquela comissão do Senado, ele vai dizer que é preferível que venham quinze manifestantes. (...) Dirá: "traz essa lista de reivindicações, vamos ver o que podemos fazer". A primeira coisa que ele vai fazer é arranjar uma solução para os quinze. Se ele não pode salvar todos os negros, deixa salvar esses quinze. Não é natural? Agora, nós sabemos que no dia em que tiver uma manifestação lá na praça do congresso, com um milhão de negros, o discurso será diferente. Vou plagiar o Lenine, que é a inteligência política mais importante do século XX: "quando for levar uma mensagem a uma classe social, tem que levar essa mensagem a todas as classes sociais". Nunca vai 
despertar o operário falando com o operário, é falando com o burguês que se acorda o operário. Sabe por quê? Porque o operário só ouve o burguês. Então, no dia que ele ouvir um burguês dizendo: “isso é uma porcaria, temos que pôr o socialismo”... O negro é a mesma coisa, só vai acordar quando tiver um monte de branco dizendo: "eu não aguento mais esse racismo!" Por quê? Porque o negro se reflete no branco. A maioria dos negros quer ser branco e a primeira coisa que fazem para ser brancos é negar que são negros. Essa é atitude de desafio do Movimento Negro - MOVIMENTO NEGRO. Já ouvi muitos dizerem: “mas porque essa provocação, agressão? Porque não colocam outro nome?” Para melhorar não diz "negro", ou seja, é a realidade que não pode ser dita. A realidade não deve ser pronunciada. Então, penso ao contrário. Nós devemos só procurar entender. Difundir o que a gente entende, o melhor do que a gente entende, para aquilo ser o ponto de partida para elaborações mais sofisticadas e de um entendimento mais profundo. É com esse entendimento que vamos assustar até a elite do "outro lado".

Já houve delegação no Palácio do Planalto para falar com o presidente Sarney. Era um grupo, de evidentemente quase quinze negros. Ele ficou assustado de conversar com aquela gente, não gostou não. Eram negros muito... atrevidos. Sabem uma pessoa maravilhosa, democrata que tinha pavor da gente? Um governador paulista. Ele ficava muito mal quando tinha que conversar com a gente do Movimento Negro. Como ele era democrata, recebia. Era horrível porque iam ali uns pretos chatos. Eles sabiam de tudo. O governador ficava em palpos de aranha. (...) Então, é esse movimento que pode mudar alguma coisa, mas é de massa. Essa massa toda inerme, infantilizada, fascistizada que a gente conhece. É uma tarefa de Hércules, acordar essa gente toda. Mas, não tem outro caminho, por isso que o nosso caminho é pedagógico. É educativo. Porque se não analisar profundamente a coisa pode-se pensar que com meia granada de mão e meia dúzia de caras se põe o sistema para correr -. Este é o erro que cometem os companheiros lá na favela. (...) Ele pode pensar que vai com uma arma, vai nada, o inimigo vende arma para ele. Os militares têm helicópteros, que vão comprar em Miami e tirar até vantagem do preço disso. Então, é ótimo que o favelado resista, o sistema quer mesmo que eles resistam. Não quer só que a favela do Rio de Janeiro resista, quer que no Maranhão também resista. O governo pode criar mais uma arma nacional, mais força nacional. Tropas de choque de todos os tipos. Em vez de ter dois milhões e meio, terão vinte e cinco milhões de polícias. Essa sociedade não é o caminho da gente. O caminho é encher a orelha dele de críticas, de coisas insuportáveis. E essas coisas só vêm do conhecimento da verdade, da desmascaração. Caso estivermos armados com uma teoria que realmente explique as coisas. 
Não a teoria pra consumir na padaria com umas cervejas, mas uma teoria que dê trabalho para esses sociólogos e ideólogos do status quo racista. Vejam como eles rechaçam facilmente os argumentos que são contra - apresentando o estado como democrático. "O Brasil não tem mais ditadura, o problema dessa gente é de educação”. (...) Se for com uma teoria conversa-fiada para cima do opressor, ele devolve outra teoria-boba para você. Deve-se dizer: não, esse Estado é fascista. É o resultado de uma acumulação de experiência que veio desde o tempo da escravidão. Ele não melhorou, porque não mudou nada nem ninguém, nem as pessoas nele mudam. O pai aposenta com 80 anos e dá a vaga para o filho. Não muda nada, eu conheço todos vocês, e vamos estudar para conhecer todos. Você é neto de fulano de tal. Mas é com isso que a gente tem que lutar e fazer. Desmascarar o tipo. Deve-se estar armado de uma teoria que permita conhecer. Não se pode contar apenas com bobagens, como a hipótese de um voto democrático. Agora, não se pode criticar nada porque é uma ameaça à democracia recente. Justo por ser recente, deve ser criticada e melhorada. No entanto, isso só pode ser feito com mobilização de massa e participação. Nunca com o silêncio, a morte da análise, a recusa da crítica. É preciso questionar. É preciso fazer perguntas. No Brasil não fazemos. Aqui "a democracia é perfeita, é maravilhosa; o senhor não votou?” Espere mais cinco anos. Eu encerrarei com aquela frase do Lord Keynes, que era da aristocracia, era rico, "no longo prazo estaremos todos mortos”! Por isso, dizem para nós esperarmos mais cinco anos, para talvez morrermos. Aí a nova geração começa tudo do zero de novo. Obrigado. 